UDC 546.261:539.218

\author{
Q. Zhu* (Stony Brook, NY, US) \\ O. D. Feya (Dolgoprudny city, Moscow Region,
}

Russian Federation)

S. E. Boulfelfel ( Stony Brook, NY, US)

A. R. Oganov** (Stony Brook, NY, US; Dolgoprudny city, Moscow Region, Russian Federation; Xi'an, P. R. China)

*alecfans@gmail.com

**artem.oganov@sunysb.edu

\title{
Metastable host-guest structure of carbon
}

A family of metastable host-guest structures, the prototype of which is a tetragonal tP9 structure with 9 atoms per cell has been found. It is composed of an 8-atoms tetragonal host, with atoms filling channels oriented along the c-axis. The tP9 structure has a strong analogy with the recently discovered Ba-IV-and Rb-IV-type incommensurate structures. By considering modulations of the structure due to the variations of the host/guest ratio, it has been concluded that the most stable representative of this family of structures has a guest/host ratio of 2/3 and 26 atoms in the unit cell (space group $\mathrm{P}_{2} / \mathrm{m}$ ). This structure is $0.39 \mathrm{eV} /$ atom higher in energy than diamond. We predict it to have band gap $4.1 \mathrm{eV}$, bulk modulus $384 \mathrm{GPa}$, and hardness 61-71 GPa. Due to the different local environments of the host and guest atoms, we considered the possibility of replacing carbon atoms in the guest sublattice by Si atoms in the tP9 prototype and study the properties of the resulting compound $\mathrm{SiC}_{8}$, which was found to have similarly remarkably high bulk modulus $361.2 \mathrm{GPa}$ and hardness 46.2 GPa.

Keywords: density functional theory, evolutionary algorithm, incommensurate crystal, silicon carbide.

\section{INTRODUCTION}

Carbon is a unique element in the sense that it adopts a wide range of structures, from superhard insulators (diamond and lonsdaleite) to ultrasoft semimetals (graphite, an excellent lubricant) and even superconductors (intercalated graphite and fullerenes, doped diamond) [1-5]. Among the solid phases, only graphite, diamond and bc 8 phase (predicted to be stable at pressures above $1 \mathrm{TPa}$ ) have stability fields on the phase diagram. However, the number of all possible metastable phases is in principle infinite, and due to directional covalent bonding, many metastable carbon phases are known, and have extremely long (technically indefinite) lifetimes. Much work both in experiment and theory has been done to search for novel carbon phases with special properties (such as metallic conductivity, hardness, etc.) [6-17]. Until now, it has not been imagined that carbon could also adopt a host-guest structure.

The nature of host-guest structures of compressed metals is still somewhat puzzling, given their ubiquity and complex and relatively open topologies [18]. Since Ba-IV was first solved experimentally [19, 20], a series of complex phases with composite host-guest structures were found for alkali, alkali earth, group 15 and 16 
elements (e.g., [21-29]). Recently, aluminum was also predicted to adopt a similar host-guest type structure at extremely high pressure (about $1 \mathrm{TPa}$ ) [30]. To the best of our knowledge, group 14 elements have not been reported to have host-guest structures. However, our structure searches uncovered such structures as metastable states. Although metastable, rather than thermodynamically stable, these are of great interest for the understanding of carbon polymorphism and of the nature of host-guest structures. The newly found structures provide an interesting way of constructing a host-guest network, suitable for low-coordinate atoms and alternative to the known Ba-IV and Rb-IV host-guest structure types.

\section{COMPUTATIONAL METHODS}

Evolutionary structure searches were performed using the USPEX code [31-33] in conjunction with ab initio structure relaxations using density functional theory (DFT) [34, 35] within the Perdew-Burke-Ernzerhof (PBE) generalized gradient approximation (GGA) [36], and the all-electron projector-augmented wave [37, 38] (PAW) method, as implemented in the VASP code [39]. We used a PAW potential with $\left[1 s^{2}\right]$ core, plane wave kinetic energy cutoff of $600 \mathrm{eV}$, and Brillouin zone sample with reciprocal space resolution of $2 \pi \times 0.05 \AA^{-1}$, which ensured excellent convergence of total energies, stresses, and energy differences. These calculations correctly yielded the ground states - graphite at normal conditions, diamond at high pressures, and bc8 at ultrahigh pressures above $1 \mathrm{TPa}$ [31].

To ensure that the obtained structures are dynamically stable, we calculated phonon frequencies across the Brillouin zone using the frozen-phonon method as implemented in the PHONOPY code [40]. For obtaining the electronic density of states (DOS) of the 9-atom $t P 9$ and $\mathrm{SiC}_{8}$ structures we used $5 \times 5 \times 8$ grid for selfconsistent calculations, followed by a non-self-consistent calculation with a $10 \times 10 \times 16$ k-points grid, and same-resolution grids for the 26-atom modulated structure. Band structures were calculated using the hybrid functional HSE06 [41]. Bader analysis [42] was performed using the code [43]. We estimated hardnesses using the Lyakhov-Oganov approach [16] and the Chen-Niu model [44]; for the latter, bulk and shear moduli are required - these were computed within the VoigtReuss-Hill averaging scheme [45-47] of the elastic constants computed by finite strain method.

\section{RESULTS}

\section{Host-guest structure of pure carbon}

We have performed structure searches at 0, 5, $10 \mathrm{GPa}$ with 3, 4, 6, 9, 12 atoms per unit cell, respectively. Apart from the already known structures (diamond, lonsdaleite, bc8, M-carbon, bct4, etc.), our simulations also found a tetragonal host-guest structure. This composite structure is shown in Fig. 1, $a$, and consists of a host sublattice ( 8 atoms in the unit cell with lattice parameters $a=b=4.560 \AA$ and $c=2.556 \AA$ ). The symmetry of the host sublattice is $P 4_{2} / \mathrm{m}$; there are two $4 \mathrm{j}$ Wyckoff sites $-\mathrm{C}_{\mathrm{h} 1}(0.288,0.781,0.223)$ and $\mathrm{C}_{\mathrm{h} 2}(0.839,0.531,0.266)$. The guest atoms occupy the sites $\mathrm{C}_{\mathrm{g}}(0,0,0)$ and there is only 1 guest atom in the unit cell. The space group of the whole host-guest structure is lowered to $P 4$. This structure has strong analogy with well-known Ba-IV and Rb-IV host-guest structure as shown in Fig. 1, c, 1d. The main difference is that carbon prefers low coordination numbers (in this structure, $\mathrm{C}$ atoms are in a distorted fourfold coordination), while the average coordination number of host and guest atoms is typically 8-10 in BaIV or Rb-IV type structures. tP9 is a low-coordinate host-guest structure. 


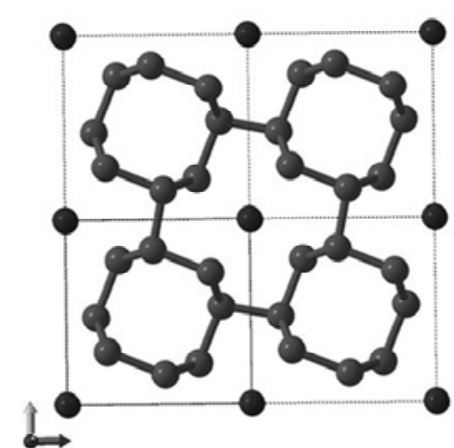

$a$

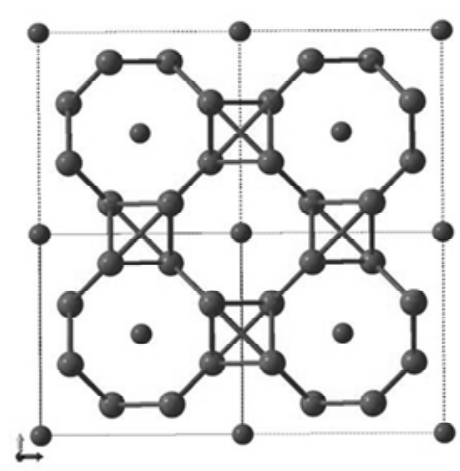

$c$

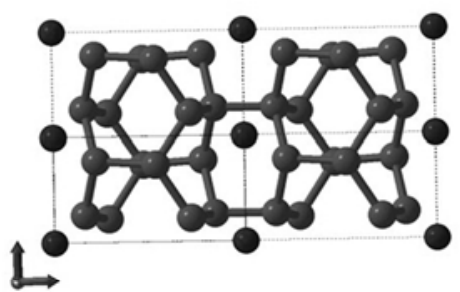

$b$

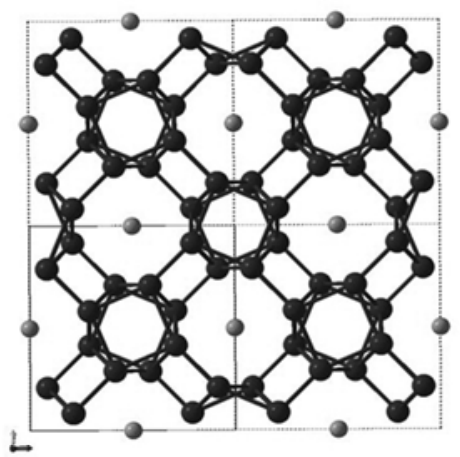

$d$

Fig. 1. Crystal structure of $t P 9$-carbon in two projections $(a, b)$; also shown are Ba-IV $(c)$ and Rb-IV (d) structures.

Bond lengths within the host sublattice vary between 1.53-1.57 $\AA$, while the shortest host-guest bond is $1.74 \AA$. Bond angles within the host sublattice are $107^{\circ} 90^{\prime}$ and $119^{\circ} 01^{\prime}$; guest-host bonds form angles $105^{\circ} 73^{\prime}$ and $124^{\circ} 91^{\prime}$. These values are close to the ideal angles of $109^{\circ} 28^{\prime}$ and $120^{\circ}$ for $s p^{3}$ - and $s p^{2}$ hybridizations.

To compute the hardness of $t P 9$, we used the Lyakhov-Oganov [16] and ChenNiu [44] models - the results of these completely independent models being very similar, 70.4 and $72.8 \mathrm{GPa}$, respectively. The bulk modulus is remarkably high, $388 \mathrm{GPa}$ (for comparison, the bulk modulus of diamond computed at the same level of theory is $431 \mathrm{GPa}$ [15]). Its density is $3.37 \mathrm{~g} / \mathrm{cm}^{3}$.

We have calculated the enthalpies of the host-guest structure and some other well-known and hypothetical structures as a function of pressure (Fig. 2). Our host-guest structure is $0.55 \mathrm{eV} /$ atom higher in energy than diamond at $P=0$, but more energetically favorable than the predicted superdense allotropes [15]. At the same time, it is dynamically stable (i.e. there are no imaginary phonon frequencies, Fig. 3) and, once synthesized, may exist as a metastable phase. The electronic band structure of $t P 9$ is shown in Fig. 4. According to the HSE06 hybrid functional (known to rather accurately estimate the band gaps of carbon allotropes), it is a semiconductor with an indirect band gap of $3 \mathrm{eV}$ at zero pressure.

The geometric difference between host and guest sublattices invites the question of possible charge transfer (as found in $\gamma$-boron [48]). We performed Bader analysis of the total charge density of $t P 9$-carbon and results are presented in Table 1. As one can see, although different carbon sites have very different local 
environments and there is a large variation of Bader volumes, charge transfer is quite modest in this structure, and Bader charges are rather small.

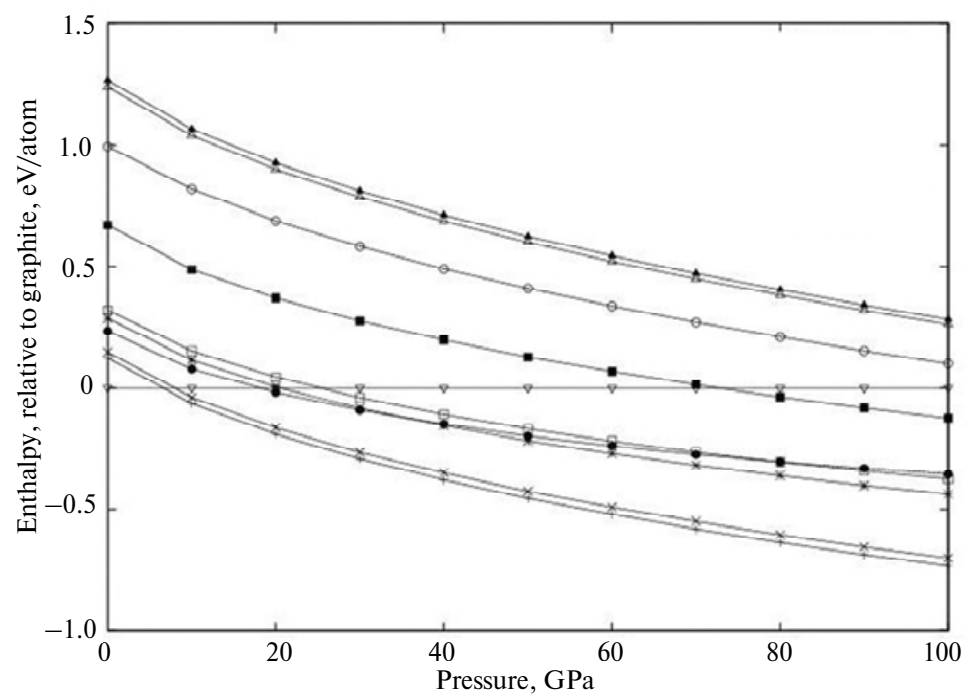

Fig. 2. Enthalpies of various carbon structures, relative to graphite: diamond $(+)$, lonsdaleite $(\times)$,

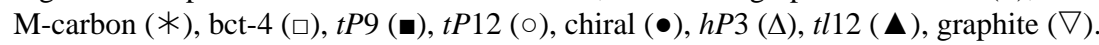

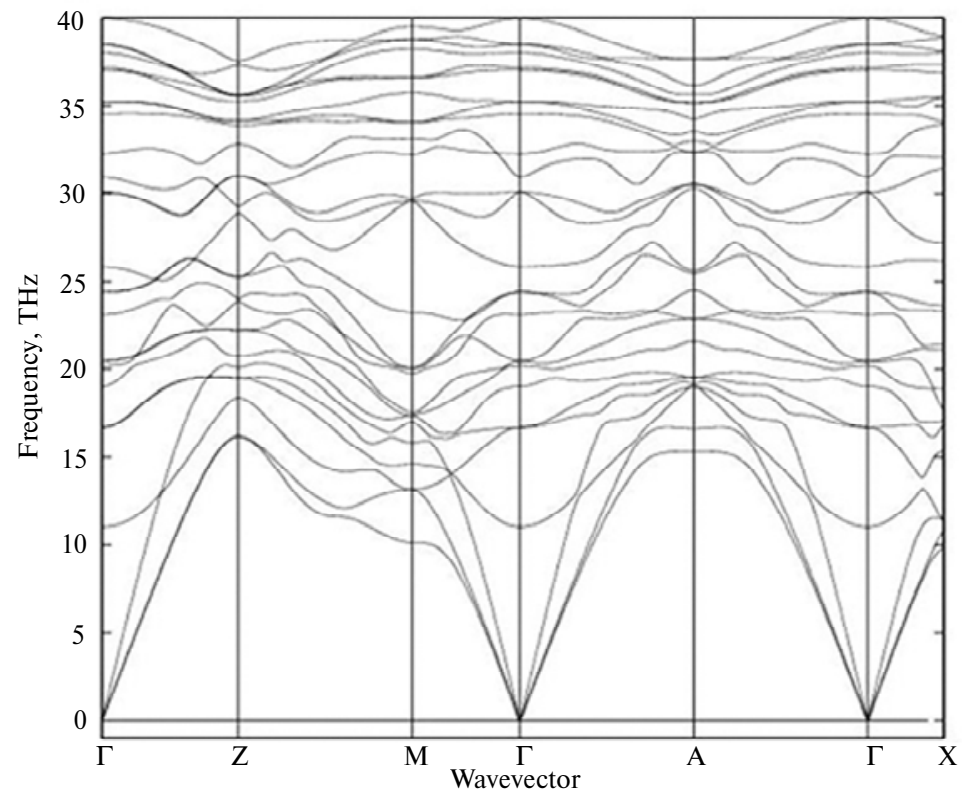

Fig. 3. Phonon dispersion curves of $t P 9$-carbon. The absence of imaginary frequencies demonstrates dynamical stability.

In the next section we explore an additional degree of freedom that host-guest structures have, namely the host/guest periodicity ratio. This allows us to obtain a more stable host-guest structure and explore its properties. 

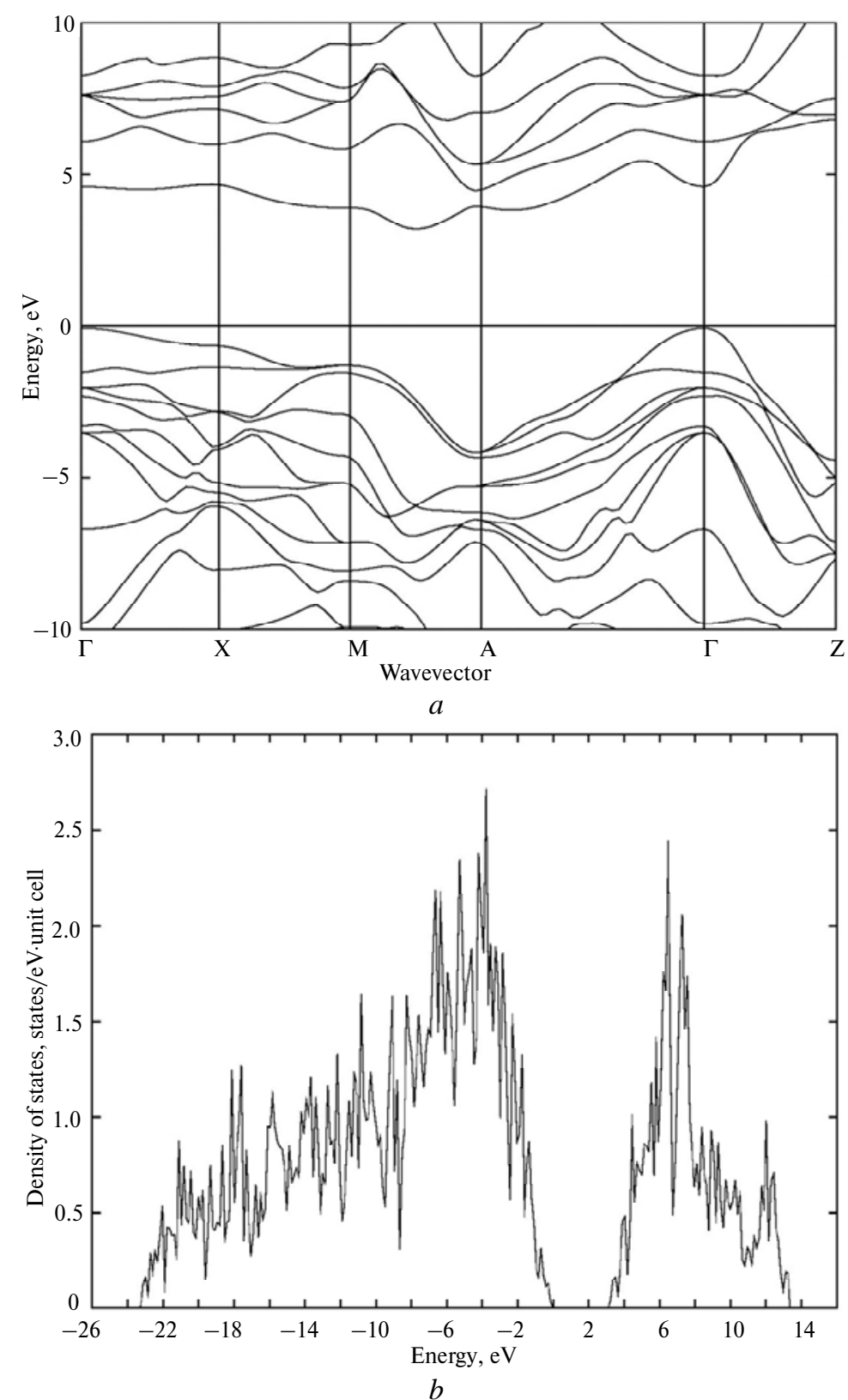

Fig. 4. Density of states ( $a$ ) and band structure $(b)$ of $t P 9$-carbon at 0 GPa, computed with the HSE06 hybrid functional.

Table 1. Bader charges and volumes in tP9 carbon. Space group $P \overline{4}$, lattice parameters $a=b=4.560 \AA$ and $c=2.556 \AA$

\begin{tabular}{c|c|c|c|c|c}
\hline Position & $x$ & $y$ & $z$ & Bader charge & $\begin{array}{c}\text { Bader volume, } \\
\AA^{3}\end{array}$ \\
\hline $\mathrm{C}_{\mathrm{g}}$ & 0.0000 & 0.0000 & 0.0000 & -0.0580 & 6.8912 \\
$\mathrm{C}_{\mathrm{h} 1}$ & 0.2881 & 0.7804 & 0.2232 & -0.0275 & 5.9987 \\
$\mathrm{C}_{\mathrm{h} 2}$ & 0.8394 & 0.5307 & 0.2662 & +0.0423 & 5.4811 \\
\hline
\end{tabular}




\section{Optimization of the host-guest ratio - exploring possible incommensurability}

Since most host-guest structures of metals are found to be incommensurate, we decided to explore this possibility here. To this end, we used the method of Arapan et al. [22] and performed calculations for a set of commensurate approximants with different $C_{g} / C_{h}$ ratios $\left(C_{g}\right.$ and $C_{h}$ are the numbers of guest and host cells in an approximant supercell, respectively). Because the total energy is a continuous function of structural parameters, after interpolating the energy as a function of $\mathrm{C}_{\mathrm{g}} / \mathrm{C}_{\mathrm{h}}$, one can obtain the minimum energy and the $\mathrm{C}_{\mathrm{g}} / \mathrm{C}_{\mathrm{h}}$ ratio corresponding to it. If $\mathrm{C}_{\mathrm{g}} / \mathrm{C}_{\mathrm{h}}$ is an irrational number, this would indicate an incommensurate modulation of the structure. Fig. 5 and Fig. 6 show the calculated energies and enthalpies of various commensurate structures; on can see that the commensurate structure with the $C_{g} / C_{h}=2 / 3$, containing 26 atoms in the unit cell, is energetically optimal. Parameters of this structure are given in Table 2.

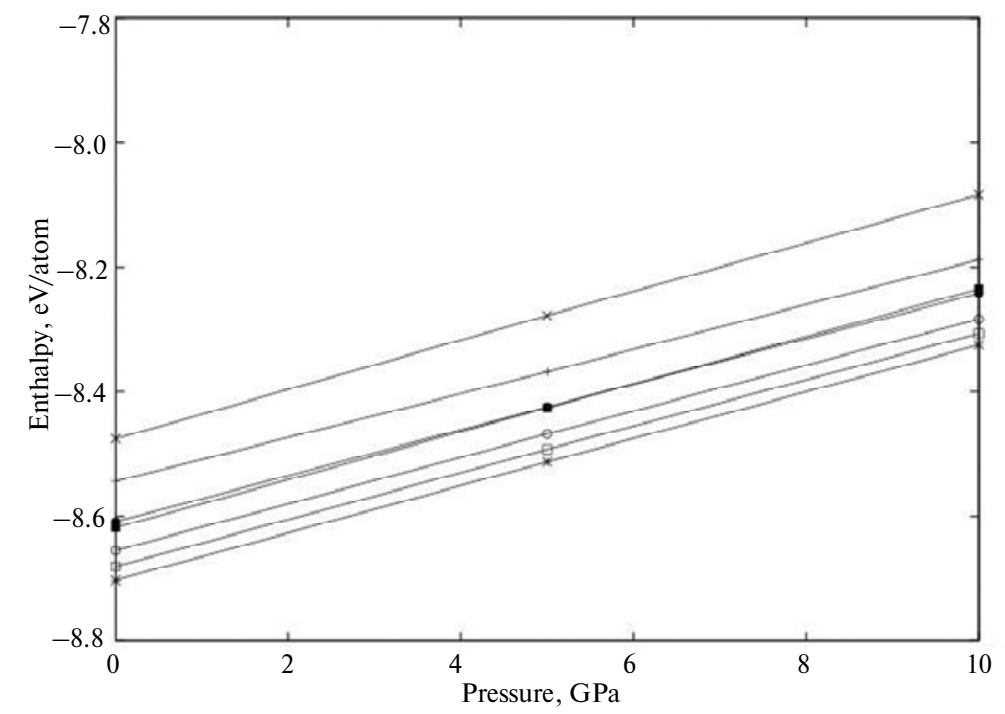

Fig. 5. Enthalpies of various commensurate analogues as a function of pressure: $1^{*} 1(+), 1^{*} 2(\times)$, $2 * 3(*), 3 * 4(\square), 3 * 5(\bullet), 4 * 5(0), 9 * 10(\bullet)$.

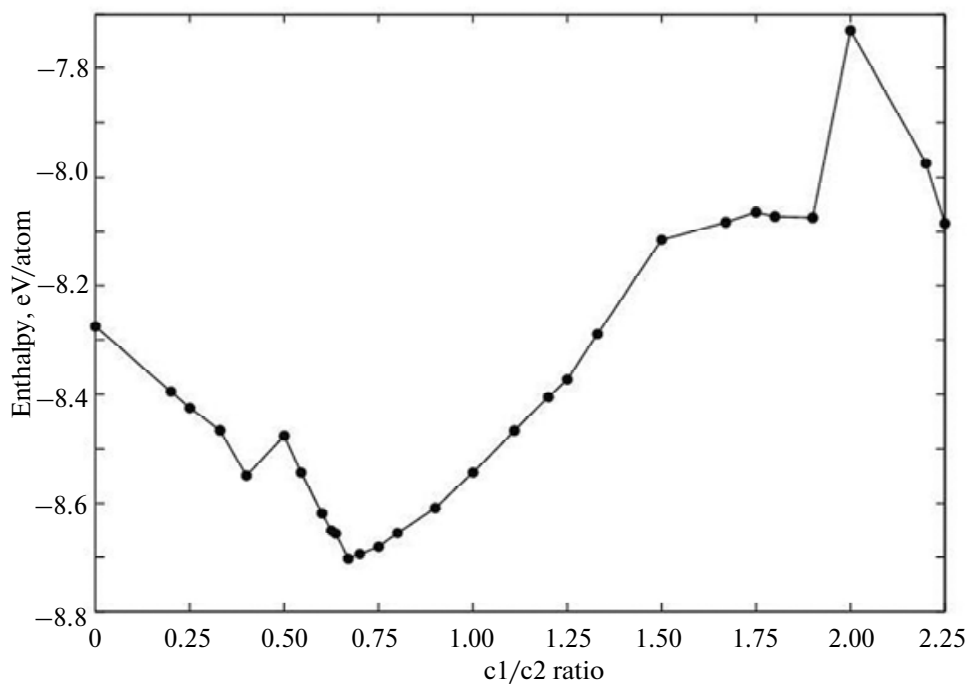

Fig. 6. Total energies of various commensurate structures. Outside the range $c 1 / c 2 \in[0.5,1.5]$ the structure spontaneously changes into very different topologies. 
Table 2. Bader charges and volumes in the $2 / 3$ modulated structure. Space group $P 4_{2} I m$, lattice parameters $a=b=4.600 \AA, c=7.499 \AA$

\begin{tabular}{c|c|c|c|c|c}
\hline Position & $x$ & $y$ & $z$ & Bader charge & $\begin{array}{c}\text { Bader volume, } \\
\AA^{3}\end{array}$ \\
\hline $\mathrm{C}_{\mathrm{g}-2 \mathrm{a}}$ & 0.0000 & 0.0000 & 0.0000 & -0.0669 & 7.5665 \\
$\mathrm{C}_{\mathrm{h} 1-8 \mathrm{k}}$ & 0.2672 & 0.8027 & 0.0721 & +0.0337 & 6.1236 \\
$\mathrm{C}_{\mathrm{h} 2-8 \mathrm{k}}$ & 0.8319 & 0.5138 & 0.0892 & -0.0126 & 5.9542 \\
$\mathrm{C}_{\mathrm{h} 3-8 \mathrm{k}}$ & 0.6413 & 0.6073 & 0.2500 & -0.0044 & 5.9274 \\
\hline
\end{tabular}

The new $2 / 3$ structure is more stable than $t P 9$-carbon by $0.16 \mathrm{eV} /$ atom. It is also dynamically stable, as we can see in Fig. 7. Its lattice parameters are slightly different from those of $t P 9$-carbon: $a=b=4.600 \AA$, but $c=7.499 \AA$, approximately three times the value of the c-parameter of the $1 / 1$ structure.

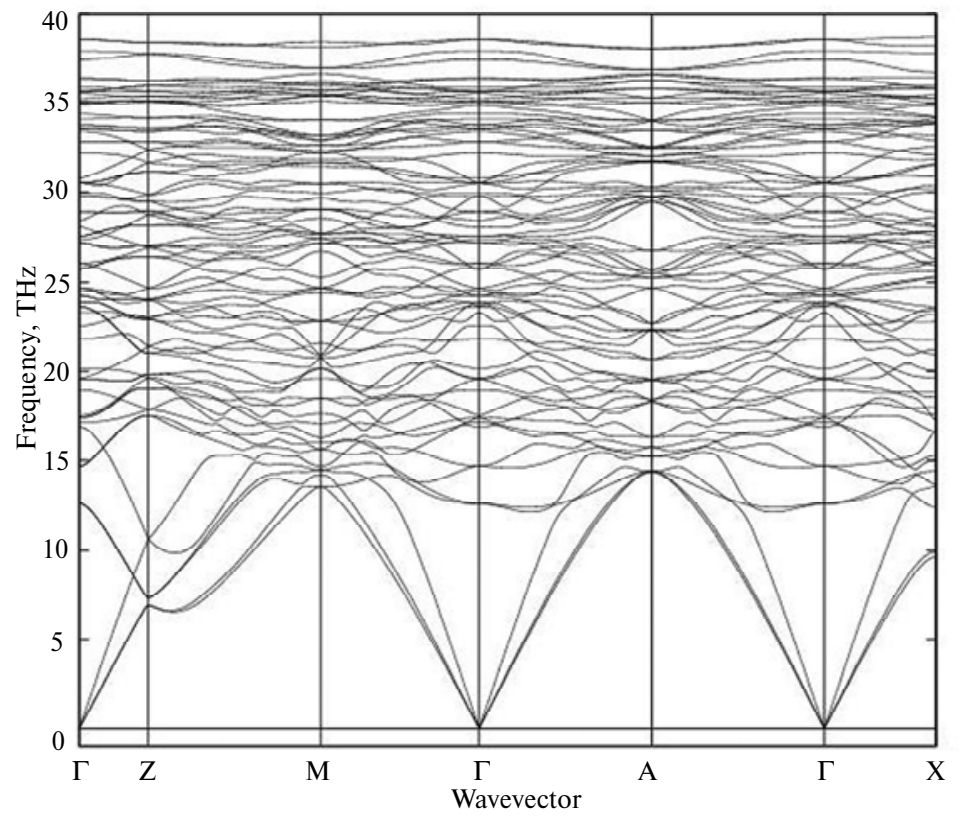

Fig. 7. Phonon dispersion curves of the $2 / 3$ commensurate modulation of $t P 9 C$ carbon.

The band structure of the 2/3-structure is shown in Fig. 8, and electronic densities of states computed with PBE and HSE06 are shown in Fig. 9. The computed HSE06 band gap is $4.1 \mathrm{eV}$ (much higher than $3.0 \mathrm{eV}$ computed for the $t P 9$ structure). Its hardness is computed to be $60.6 \mathrm{GPa}$ using model [16] and 70.6 with model [42], the computed bulk modulus is $383.6 \mathrm{GPa}$. The density of this phase of carbon is $3.25 \mathrm{~g} / \mathrm{cm}^{3}$.

\section{$\mathrm{SiC}_{8}$ compound}

We have investigated the possibility of replacing one of the sublattices with another element. When we replaced the guest carbon atom by a larger silicon atom, the structure remained dynamically stable (Fig. 10). Just like the host, the guest atoms are 4-coordinate with a noticeably larger bond lengths of $1.70 \AA$ (the normal single $\mathrm{C}-\mathrm{C}$ bond length is $1.54 \AA$ ). Thus, it is natural to place a large atom, such as $\mathrm{Si}$, in the guest sublattice, and we did it for the parent 1/1 structure. The 
structure has space group $P \overline{4}$, with two independent 4 h Wyckoff positions occupied in the host sublattice by $\mathrm{C}$ atoms, with coordinates $(0.694,0.232,0.241)$ and $(0.165,0.477,0.257)$, and the $\mathrm{Si}$ atom in the guest sublattice occupies the $1 \mathrm{a}$ site at $(0,0,0)$; the lattice parameters are $a=b=4.830 \AA$ and $c=2.522 \AA . \mathrm{SiC}_{8}$ is found to have interesting physical properties. Its bulk modulus is $361.2 \mathrm{GPa}$; the hardness computed with model [16] is $46.2 \mathrm{GPa}$, i.e. the material is superhard. The HSE06 [41] band gap is $1.8 \mathrm{eV}$. This result is interesting for absorption of solar light - with possible applications in photocatalysis. Density of states, calculated at different pressures using the HSE06 functional, is shown in Fig. 11. We can see that the band gap slightly increases with pressure - opposite to the normal tendency, but similar to diamond [49]. The density of $\mathrm{SiC}_{8}$ is $3.49 \mathrm{~g} / \mathrm{cm}^{3}$.

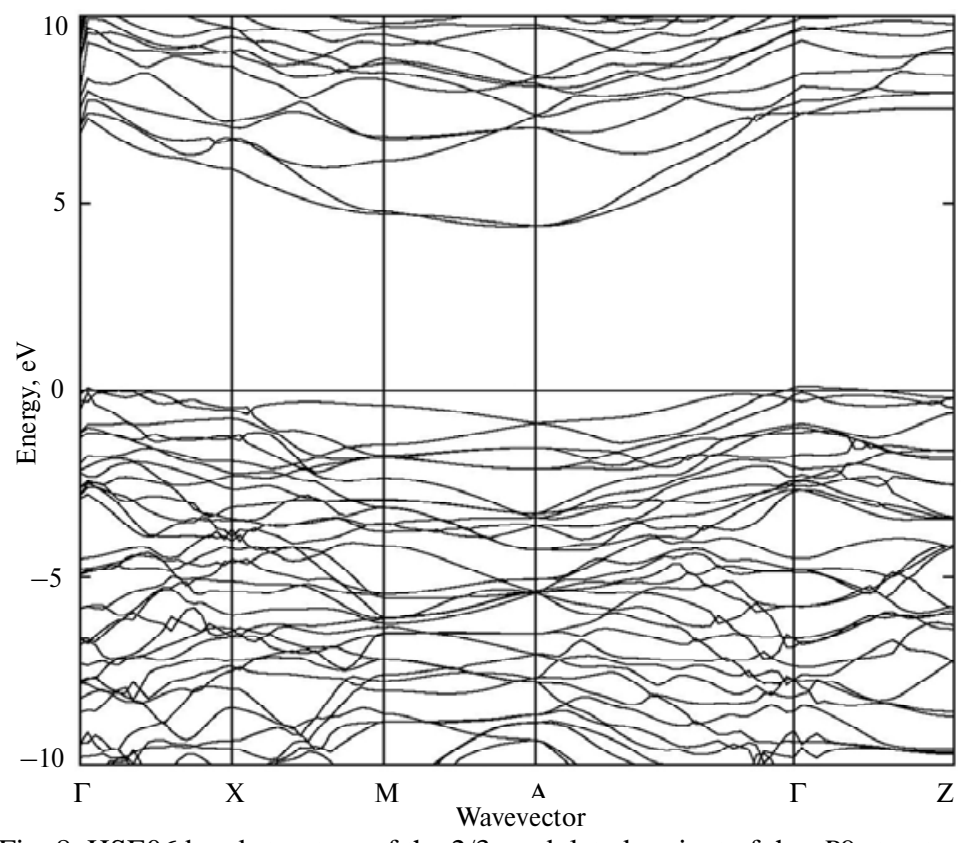

Fig. 8 . HSE06 band structure of the $2 / 3$ modulated variant of the $t P 9$ structure.

It is interesting to compare energy of the isochemical mixture of diamond-like $\mathrm{Si}$ (the ground state of $\mathrm{Si}$ ) and diamond $\mathrm{C}$ with the energy of our $\mathrm{SiC}_{8}$ structure. We find that $\mathrm{SiC}_{8}$ is $0.27 \mathrm{eV} /$ atom less stable than the isochemical mixture of diamond-structured Si and $\mathrm{C}$. The enthalpy of formation from true ground states of the elements, diamond-like Si and C-graphite, is $0.38 \mathrm{eV} /$ atom.

In the $\mathrm{Si}-\mathrm{C}$ system, there is a stable phase $\mathrm{SiC}$. We have explored the enthalpy of formation of $\mathrm{SiC}_{8}$ from a mixture $\mathrm{SiC}+7 \mathrm{C}$ (graphite), and the resulting value is $0.44 \mathrm{eV} /$ atom.

Results of Bader analysis are shown in Table 3. One can see a large positive charge on the Si atom.

Table 3. Bader charges and in the hypothetical compound $\mathrm{SiC}_{8}$. Space group $P \overline{4}$, lattice parameters $a=b=4.830 \AA$ and $c=2.522 \AA$

\begin{tabular}{c|c|c|c|c|c}
\hline Position & $x$ & $y$ & $z$ & Bader charge & Bader volume, $\AA^{3}$ \\
\hline $\mathrm{Si}$ & 0.0000 & 0.0000 & 0.0000 & +2.3008 & 5.4078 \\
$\mathrm{C}_{\mathrm{h} 1}$ & 0.6944 & 0.2326 & 0.2417 & -0.5854 & 7.5396 \\
$\mathrm{C}_{\mathrm{h} 2}$ & 0.1640 & 0.4769 & 0.2575 & +0.0102 & 5.8274 \\
\hline
\end{tabular}




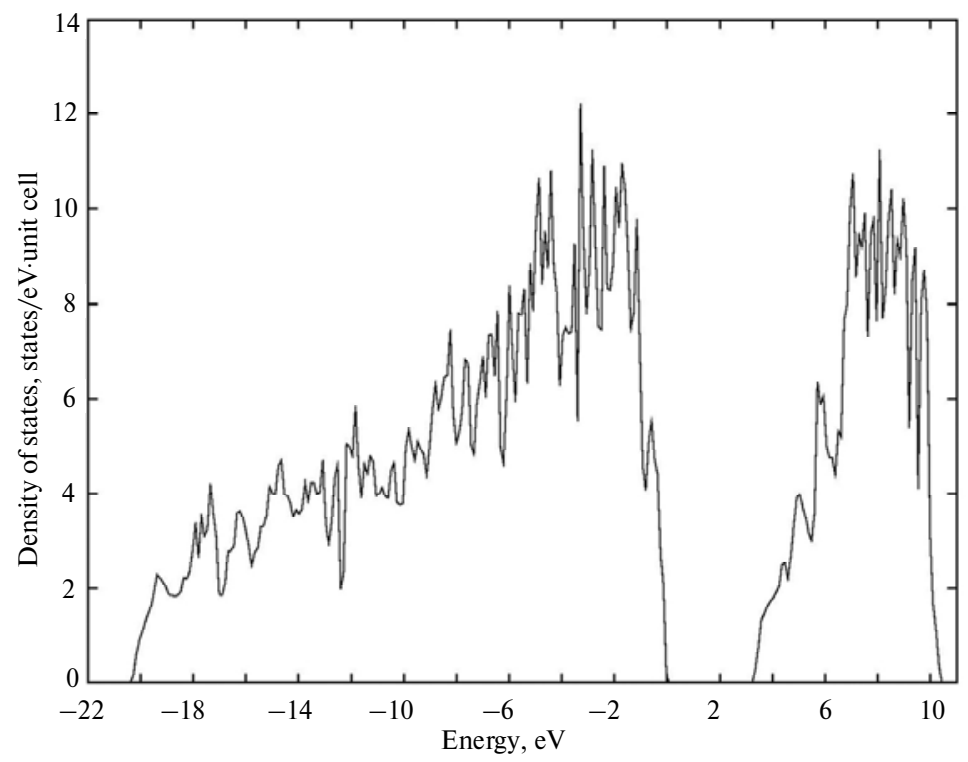

$a$

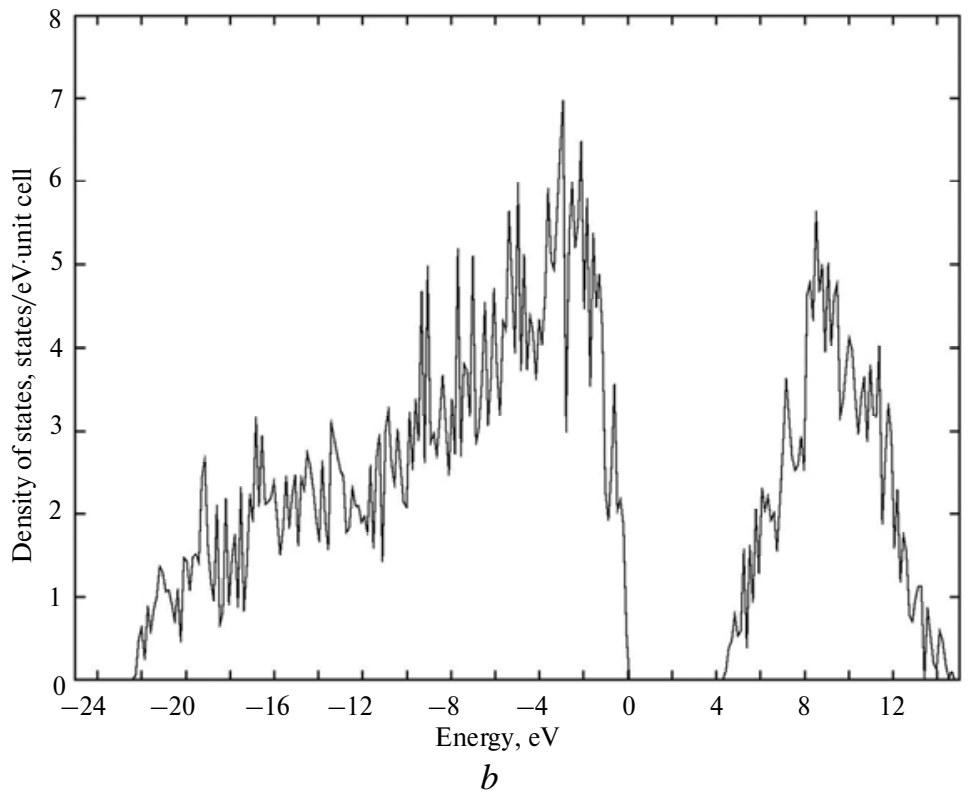

Fig. 9. Electronic density of states of the 2/3 structure computed using PBE (a) and HSE06 (b) functionals.

\section{CONCLUSIONS}

We report a novel family of metastable host-guest structures of carbon, the simplest prototype of which is the tetragonal $t P 9$ structure with 9 atoms in the unit cell. This structure consists of host $(8$ atoms/cell) and guest $(1$ atom/cell) sublattices, the guest forming 1D-chains running along the channels of the host structure. It shares similarities with well-known Ba-IV and Rb-IV host-guest structures, which become stable at elevated pressures [22], and exemplifies an extension of such structures to low-coordinate topologies. Theoretical calculations showed that it is a semiconductor with a band gap of $3.0 \mathrm{eV}$ at $0 \mathrm{GPa}$ and hardness 
70-73 GPa. This structure is $0.55 \mathrm{eV} /$ atom less stable than diamond at atmospheric pressure.

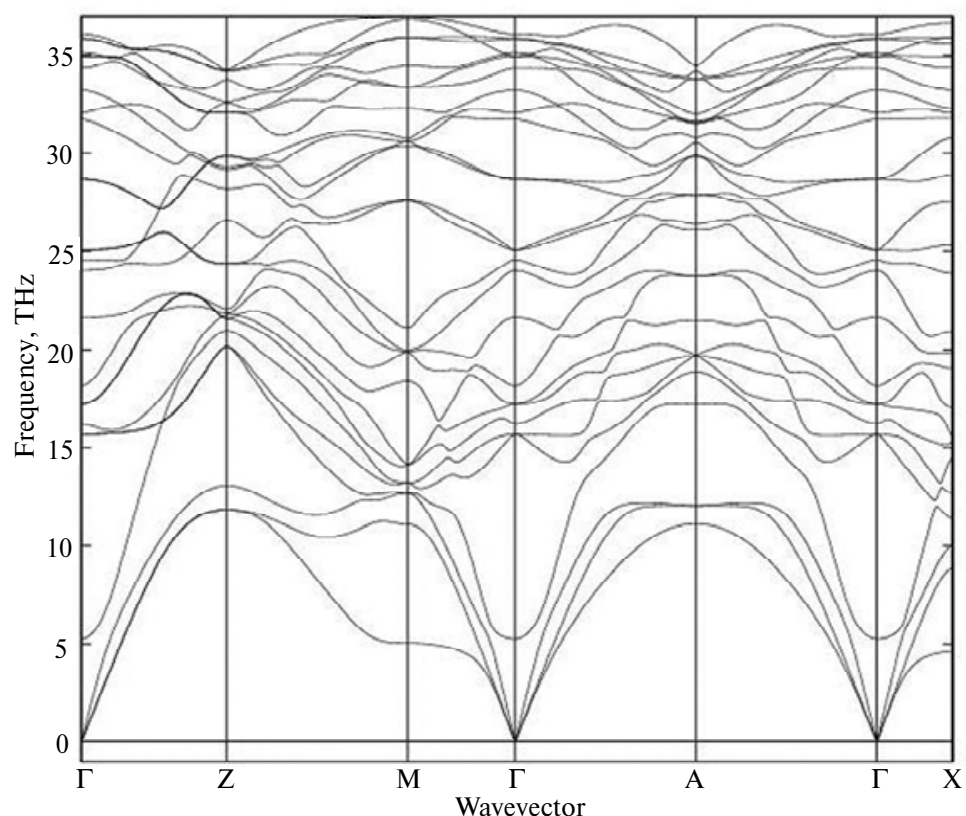

Fig. 10. Phonon dispersion curves of $\mathrm{SiC}_{8}$.
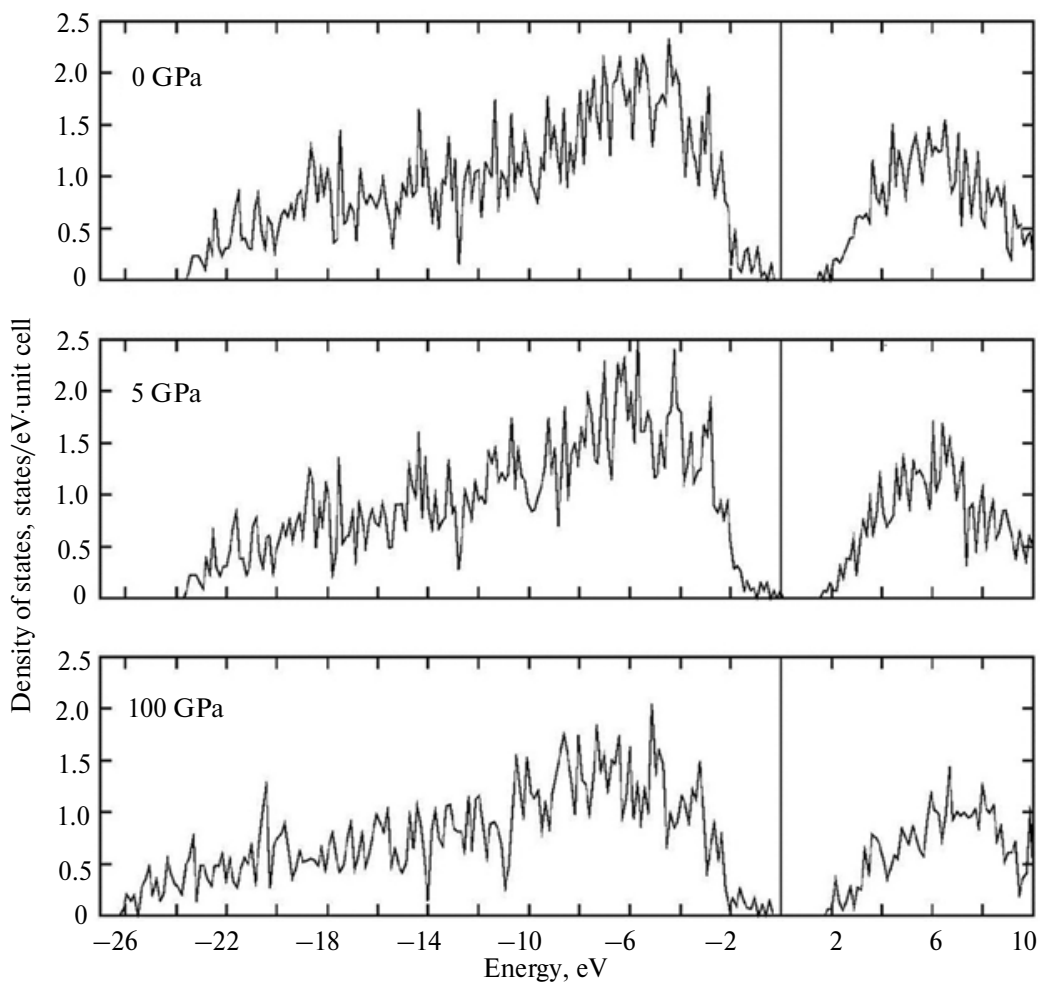

Fig. 11. The density of states for host-guest $\mathrm{SiC}_{8}$ compound at $0,5,100 \mathrm{GPa}$ computed using the HSE06 hybrid functional. 
Looking at a series of modulations of this host-guest structure, it have been found that the 2/3 modulation gives the lowest energy, lowering the energy by $0.16 \mathrm{eV} /$ atom. This optimal host-guest structure contains 26 atoms in the unit cell and is $0.52 \mathrm{eV} /$ atom less stable than graphite, and $0.39 \mathrm{eV} /$ atom less stable than diamond. Its hardness is $61-71 \mathrm{GPa}$, and its band gap is $4.1 \mathrm{eV}$.

By replacing carbon atoms in the guest sublattice with Si atoms, a hypothetical $\mathrm{SiC}_{8}$ compound has been obtained, which is $0.27 \mathrm{eV} /$ atom higher in energy than the isochemical mixture of C-diamond and diamond-type $\mathrm{Si}$. This material is predicted to have interesting properties - hardness of $46 \mathrm{GPa}$ and band gap of $1.8 \mathrm{eV}$.

These results show that host-guest structures may appear, at least as metastable phases, not only in metals, but also in non-metallic elements, and may have interesting properties. Such phases, or substitution compounds based on them, may be synthesizable.

\section{ACKNOWLEDGEMENTS}

We thank the National Science Foundation (EAR-1114313, DMR-1231586), DARPA (Grants No. W31P4Q1310005 and No. W31P4Q1210008), and the Government (No. 14.A12.31.0003) and the Ministry of Education and Science of Russian Federation (Project No. 8512) for financial support.

Повідомлясться про сімейство метастабільних структур господаргість, прототипом якого є тетрагональна структура tP9 з дев'ятьма атомами $в$ коміриі. Вона складається з восьми атомів тетрагонального господаря, шуо заповнюють канали, орієнтовані вздовж осі с. Структура tP9 аналогічна недавно відкритим Ва-IV- й Rb-IV-типам несумірних структур. Враховуючи модуляцію структури через варіацій співвідношень господар/гість, зроблено висновок, щчо найбільш стабільний представник цьього сімейства структур має відношення гість/господар - 2/3 $i 26$ атомів в елементарній коміриі (просторова група $\mathrm{P}_{2} / \mathrm{m}$ ). Енергія иієї структури на 0,39 еВ/атом вище, ніж алмазу. Ця структура, за прогнозами, повинна мати заборонену зону - 4,1 еВ, об'ємний модуль - 384 ГПа, а твердість - 61-71 ГПа. Через різні локальні стани атомів господаря $і$ гостя розглянуто можливість заміни атомів вуглецюю гостьової підгратки атомами Si в прототипі tP9 і вивчені властивості отриманої сполуки $\mathrm{SiC}_{8}$, які, як було виявлено, мають вельми високий об'ємний модуль пружності - 361,2 ГПа і твердість 46,2 ГПа.

Ключові слова: теорія функиіонала щільності, еволючиійний алгоритм, несумірний кристал, карбід кремнію.

Сообщается о семействе метастабильных структур хозяин-гость, прототипом которого является тетрагональная структура tP9 с девятью атомами в ячейке. Она состоит из восьми атомов тетрагонального хозяина, заполняющих каналь, ориентированные вдоль оси с. Структура tP9 аналогична недавно открытым Ba-IV- $u R b$ IV-типам несоразмерных структур. Учитывая модуляиию структуры из-за вариаций отношения хозяин/гость, сделан вывод, что наиболее стабильный представитель этого семейства структур имеет отношение гость/хозяин - 2/3 и 26 атомов в элементарной ячейке (пространственная группа $P 4_{2} / m$ ). Энергия этой структуры на 0,39 эB/атом выше, чем алмаза. Эта структура, по прогнозам, должна иметь запрещенную зону - 4,1 эB, модуль объемного сжатия - 384 ГПа, а твердость - 61-71 ГПа. Из-за различных локальных состояний атомов хозяина и гостя рассмотрена возможность замены атомов углерода гостевой подрешетки атомами Si в прототипе tP9 и изучены свойства полученного соединения $\mathrm{SiC}_{8}$, которое, как было обнаружено, имеет весьма высокий модуль объемного сжатия - 361,2 ГПа и твердость 46,2 ГПа.

Ключевые слова: теория функциионала плотности, эволюционный алгоритм, несоразмерной кристалл, карбид кремния.

1. Heimann R. B., Evsyukov S. E., Koga Y. Carbon allotropes: a suggested classification scheme based on valence orbital hybridization // Carbon. - 1997. - 35. - P. 1654-1657. 
2. Iijima S. Helical microtubules of graphitic carbon // Nature. - 1991. - 354. - P. 56-58.

3. Ekimov E. A., Sidorov V. A. Bauer E. D. et al. Superconductivity in diamond // Ibid. - 2004. 428. - P. 542-545.

4. Meyer J. C., Geim A. K., Katsnelson M. I. et al. The structure of suspended graphene sheets // Ibid. - 2007. - 446. - P. 60-63.

5. Wang X., Scandolo S., Car R. Carbon phase diagram from ab initio molecular dynamics // Phys. Rev. Lett. - 2005. - 95, art. 185701.

6. Mao W. L., Mao H. K., Eng P. J. et al. Bonding changes in compressed superhard graphite // Science. - 2003. - 302. - P. 425-427.

7. Buchnum M. J., Hoffman R. A. hypothetical dense 3,4-connected carbon net and related $\mathrm{B}_{2} \mathrm{C}$ and $\mathrm{CN}_{2}$ nets built from 1,4-cyclohexadienoid units // J. Am. Chem. Soc. - 1994. - 116. P. 11456-11464.

8. Winkler B., Pickard C. J., Milman V. et al. Prediction of a nanoporous $\mathrm{sp}^{2}$-carbon framework structure by combining graph theory with quantum mechanics // Chem. Phys. Lett. - 1999. 312. - P. 536-541.

9. Li Q., Ma Y., Oganov A. R. et al. Superhard monoclinic polymorph of carbon // Phys. Rev. Lett. - 2009. - 102, art. 175506.

10. Ribeiro F. J., Tangney P., Louie S. G. et al. Structural and electronic properties of carbon in hybrid diamond-graphite structures // Phys. Rev. B. - 2005. - 72, art. 214109.

11. Wang Z.W., Zhao Y.S., Tait K. et al. A quenchable superhard carbon phase synthesized by cold compression of carbon nanotubes // Proc. Natl. Acad. Sci. - 2004. - 101. - P. 1369913702.

12. Pickard C. J., Needs R. J. Hypothetical low-energy chiral framework structure of group 14 elements // Phys. Rev. B. - 2010. - 81, art. 014106.

13. Umemoto K., Wentzcovitch R. M., Saito S. et al. Body-centered tetragonal $\mathrm{C}_{4}$ : a viable $\mathrm{sp}^{3}$ carbon allotrope // Phys. Rev. Lett. - 2010. - 104, art. 125504.

14. Hoffmann R., Hughbanks T., Kertesz M. A hypothetical metallic allotrope of carbon // J. Am. Chem. Soc. - 1983. - 105. - P. 4831-4832.

15. Zhu Q., Oganov A. R., Salvado M. et al. Denser than diamond: ab initio search for superdense carbon allotropes // Phys. Rev. B. - 2011. - 83, art. 193410.

16. Lyakhov A.O., Oganov A. R. Evolutionary search for superhard materials applied to forms of carbon and $\mathrm{TiO}_{2} / /$ Ibid. - 2011. - 84, art. 092103.

17. Zhu Q., Zeng Q., Oganov A. R. Systematic search for low-enthalpy $\mathrm{sp}^{3}$ carbon allotropes using evolutionary metadynamics // Ibid. - 2011. - 85, art. 201407.

18. McMahon M. I., Nelmes R. J. High-pressure structures and phase transformations in elemental metals // Chem. Soc. Rev. - 2006. - 35. - P. 943-963.

19. Nelmes R. J., Allan D. R., Mcmahonet M. I. et al. Self-hosting incommensurate structure of barium-IV // Phys. Rev. Lett. - 1999. - 83. - P. 4081-4084.

20. Reed S. K., Ackland G. J. Theoretical and computational study of high-pressure structures in barium // Ibid. - 2000. - 84. - P. 5580-5584.

21. McMahon M. I., Degtyareva O., Nelmes R. J. Pressure dependent incommensuration in RbIV // Ibid. - 2001. - 87, art. 055501.

22. Arapan S., Mao H.K., Ahuja R. Prediction of incommensurate crystal structure in Ca at high pressure // Proc. Natl. Acad. Sci. - 2008. - 52. - P. 20627-20630.

23. Oganov A. R., Ma Y. M., Xu Y. et al. Exotic behavior and crystal structures of calcium under pressure // Ibid. - 2010. - 107. - P. 7646-7651.

24. McMahon M. I., Degtyareva O., Nelmes R. J. Ba-IV-type incommensurate crystal structure in group-V metals // Phys. Rev. Lett. - 2000. - 85. - P. 4896-4899.

25. Degtyareva O., McMahon M. I., Nelmes R. J. Pressure-induced incommensurate-toincommensurate phase transition in antimony // Phys. Rev. B. - 2004. - 70, art. 18419.

26. Fujihisa H., Akahama Y., Kawamura H. et al. Incommensurate structure of phosphorus phase IV // Phys. Rev. Lett. - 2007. - 98, art. 175501.

27. Hejny C., McMahon M. I. Large structural modulations in incommensurate Te-III and Se-IV // Ibid. - 2003. - 91, art. 215502.

28. McMahon M. I, Hejny C., Loveday J. S. et al. Confirmation of the incommensurate nature of Se-IV at pressures below 70 GPa // Phys. Rev. B. - 2004. - 70, art. 054101.

29. Hejny C., Lundegaard L. F., Falconi S. et al. Incommensurate sulfur above $100 \mathrm{GPa} / /$ Ibid. 2005. - 71, art. 020101.

30. Pickard C. J., Needs R. J. Aluminum at terapascal pressures // Nat. Mater. - 2010. - 9. P. 624-627. 
31. Oganov A. R., Glass C. W. Crystal structure prediction using ab initio evolutionary techniques: principles and applications // J. Chem. Phys. - 2006. - 124, art. 244704.

32. Oganov A. R., Lyakhov A. O., Valle M. How evolutionary crystal structure prediction works and why // Acc. Chem. Res. - 2011. - 44. - P. 227-237.

33. Lyakhov A. O., Oganov A. R., Stoke, H. T. et al. New developments in evolutionary structure prediction algorithm USPEX // Comp. Phys. Comm. - 2013. - 184. - P. 1172-1182.

34. Hohenberg P., Kohn W. Inhomogeneous electron gas // Phys. Rev. B. - 1964. - 136. P. 864-871.

35. Kohn W., Sham L. J. Self-consistent equations including exchange and correlation effects // Phys. Rev. A. - 1965. - 140. - P. 1133-1138.

36. Perdew J. P., Burke K., Ernzerhof M. Generalized gradient approximation made simple // Phys. Rev. Lett. - 1996. - 77. - P. 3865.

37. Blochl P. E. Projector augmented-wave method // Phys. Rev. B. - 1994. - 50. - P. 17953 17978.

38. Kresse G., Joubert D. From ultrasoft pseudopotentials to the projector augmented-wave method // Ibid. - 1999. - 59. - P. 1758-1775.

39. Kresse G., Furthmller J. Efficient iterative schemes for ab initio total-energy calculations using a plane-wave basis set // Ibid. - 1996. - 54. - P. 11169-11186.

40. Togo A., Oba F., Tanaka I. First-principles calculations of the ferroelastic transition between rutile-type and $\mathrm{CaCl}_{2}$-type $\mathrm{SiO}_{2}$ at high pressures // Ibid. - 2008. - 78, art. 134106.

41. Heyd J., Scuseria G. E., Ernzerhof M. Hybrid functionals based on a screened Coulomb potential // J. Chem. Phys. - 2006. - 124, art. 219906.

42. Bader R. F. W. Atoms in Molecules. A Quantum Theory. - Oxford: Oxford University Press, 1990.

43. Tang W., Sanville E., Henkelman G. A grid-based Bader analysis algorithm without lattice bias // J. Phys.: Condens. Matter. - 2009. - 21, art. 084204.

44. Chen X.-Q., Niu H., Li D. et al. Modeling hardness of polycrystalline materials and bulk metallic glasses // Intermetallics. - 2011. - 19. - P. 1275-1281.

45. Hill R. The elastic behavior of a crystalline aggregate // Proc. Phys. Soc. London. - 1952. 65. - P. 349-354.

46. Voigt W. Lehrbuch der Kristallphysik. - Leipzig: Verl. von B. G. Teubner, 1928.

47. Reuss A. Berechnung der Fliessgrenze von Mischkristallen auf Grund der Plastizitatsbedingung fur Einkristalle // Z. Angew. Math. Mech. - 1929. - 9. - S. 49-58.

48. Oganov A. R., Chen J., Gatti C. et al. Ionic high-pressure form of elemental boron // Nature. - 2009. - 457. - P. 863-867.

49. Fahy S., Chang K. J, Louie S. G. Pressure coefficients of band gaps of diamond // Phys. Rev. B. $-1987 .-35$. - P. 5856-5859.

Department of Geosciences,

Received 15.03.14

State University of New York

Center for Materials by Design,

Institute for Advanced Computational Science,

State University of New York

Moscow Institute of Physics and Technology

Northwestern Polytechnical University, Xi'an, P. R. China 